\title{
Auctioning Sovereign Bonds: A Global Cross-Section Investigation of the Price Mechanism*
}

\author{
Menachem Brenner \\ Stern School of Business, New York University \\ Email: mbrenner@stern.nyu.edu \\ Dan Galai \\ Jerusalem School of Business, Hebrew University of Jerusalem \\ Email: Dan@sigma-pcm.co.il \\ Orly Sade \\ Jerusalem School of Business, Hebrew University of Jerusalem \\ and Stern School of Business, New York University \\ Email: osade@stern.nyu.edu
}

\begin{abstract}
August 2007
* A substantial part of this paper was previously distributed under the title: "Auctioning Financial Assets: Discriminatory Vs Uniform, which Method is Preferred."

We benefited from discussions with Bill Allen, Peter Cramton, Kenneth Garbade, Avner Kalay, Michal Passerman, Jesus M. Salas, Raghu Sundaram, Avi Wohl, Yishay Yafeh, Zehavit Yosef and Jaime Zender. We thank Moran Ofir for her excellent research assistance. We would also like to thank the participants of the 2006 European Finance Association Meeting in Zurich, MTS 2006, Istanbul and FUR XIII 2006, Rome. We also benefited from comments received from the participants of seminars at Tel-Aviv University, IDC (Israel), NYU, the University of Colorado at Boulder and the Federal Reserve Bank of NY. We thank "The Caesarea Edmond Benjamin de Rothschild Center for Capital Markets and Risk" at IDC, the Krueger Center for Finance and the Zagagi Center at the Hebrew University of Jerusalem for partial financial support.
\end{abstract}




\title{
Auctioning Sovereign Bonds: Global Cross-Section Investigation of the Price Mechanism
}

\begin{abstract}
Many financial assets, especially government bonds, are issued by an auction. An important feature of the design is the auction pricing mechanism: Uniform vs. Discriminatory. Theoretical papers do not provide a definite answer regarding the dominance of one type of auction over the other. We investigate the revealed preferences of the issuers by surveying the sovereign issuers that conduct auctions. We find that the majority of the issuers/countries in our sample use a discriminatory auction mechanism for issuing government debt securities. We use a multinomial logit procedure and discriminatory analysis to investigate the mechanism choice. It was interesting to find that market oriented economies and those that practice Common law tend to use a uniform method while economies who are less market oriented and practice Civil law tend to use discriminatory price auctions.
\end{abstract}

JEL classification: G1, F3

Keywords: Uniform auction, Discriminatory auction, Treasury bonds, T-bills 


\section{Introduction}

There is a long standing debate regarding the auction system that a sovereign should use when it issues debt instruments. As early as 1960, Milton Friedman has argued that a discriminatory auction will drive out uninformed participants because of the "winner's curse" and attract better informed, typically large players. Thus, the discriminatory mechanism will be more susceptible to collusion than the uniform one. Friedman predicted that the discriminatory auction would lead to lower revenues. Alternatively, a uniform price mechanism would lead to wider participation which should result in lesser collusion and higher revenues. It is puzzling, therefore, to find that most countries, in our study, use the discriminatory price mechanism.

While sovereign bonds comprise one of the largest primary markets, they are not the only financial asset that is initially sold via auctions. In a more general setting, most of the current, public and academic, debate with respect to financial auctions revolves around two main issues. The first is whether to use an auction or another selling mechanism ${ }^{1}$. Given an auction offering, the second issue is the auction specific design. The focus of this paper is on the very important feature of the design; the pricing rule: What may explain and determine the choice between a uniform auction or a discriminatory one. ${ }^{2}$ While the focus of our paper is on sovereign bonds, the questions that are related to the choice of a pricing mechanism in financial auctions should be of interest to a wider audience.

It is important to note at the outset that this is a challenging academic question which has not been resolved. The academic literature since Friedman (1960) is not conclusive regarding the optimal offering system and pricing mechanism for repetitive bond auctions. In addition to the on going academic debate this is also a very important practical issue that countries are coping with. Many countries in our sample have moved from one pricing rule to another after debating the issue and in the case of the U.S. devoting time and resources for experimentation. The so called "Salomon Squeeze" in

\footnotetext{
${ }^{1}$ The recent Google and Morningstar auctions, may have started a new approach to IPOs of stocks in the U.S. and elsewhere.

${ }^{2}$ In the Uniform Price Auction (UPA) (also known as Single Price Auction), the objects are awarded to the bidders that bid above the market clearing price. All bidders pay the same price, the market clearing price, for the entire quantity that they are awarded. In the Discriminatory Auction (DA) (also known as Pay Your Bid Auction or Multiple Prices Auction), the objects are also awarded to the bidders that bid above the market clearing price. However, each bidder pays the price that he bid.
} 
May 1991 (Jagadeesh 1993) has triggered an examination of the auctioning system, in particular the pricing mechanism. The US treasury decided to carry out an experiment using the two pricing rules in parallel, for different bond issues. The results of this experiment are documented in Malvey, Archibald, and Flynn (1995), Nyborg and Sundaresan, (1996), Malvey and Archibald (1998) and Goldreich (2007). While the experiment results did not provide a significant revenue improvement in the uniform mechanism versus the discriminatory, additional considerations have contributed to the decision to switch to the uniform price mechanism,

In the analysis of the markets for sovereign bonds, one must take into account the three major interested parties or stakeholders: the first is issuer, be it the treasury or the central bank. The issuer's objective is to maximize revenues over time taking into account long term considerations. Hence, in addition to short term consideration like the revenues from a forthcoming specific auction, the issuer cares about the structure and quality of the secondary market, including the symmetry of allocation and the likelihood of collusion in the auction or the secondary market since it will affect the cost of future issues. In addition the sovereign may have additional objectives that can be related to macro economic considerations or foreign policy considerations such as the level of foreign holding of its debt. The second stakeholders are the intermediaries, who serve as the underwriters, designated dealers, dealers and brokers. The designated dealers profit from purchasing the issue and selling it to the public which can be either institutional investors or private investors. Their goal is to maximize the profit from this activity. They can potentially gain from market inefficiencies. The third stakeholder is the public, including financial institutions who invest in these debt instruments. They, of course, would like to pay the lowest possible price, at the same time, they gain from market liquidity and efficiency.

Our research consists of two parts. In the first part we document the recent auction mechanism designs employed by treasuries and central banks around the globe (their revealed preferences). In the second part, we analyze, in a cross sectional setting, the factors that are potentially related to the choice of a mechanism by country. Given our results, we provide an explanation that is consistent with our empirical findings that take into account the different bargaining power of the three stakeholders. 
Even though the primary market for government debt is one of the largest financial markets in the world, there is no source of public data that provides cross country information about treasury auctions. This information can only be obtained by collecting data directly from each country. We have contacted Treasury ministries and central banks around the globe and received answers from 48 countries. We have carefully screened this unique data base and documented which country is using what mechanism (discriminatory, uniform, both or other pricing rule). Our sample consists of countries from different continents, different populations and economic size, including almost all (83\%) the OECD countries. ${ }^{3}$

Most countries that responded to our survey use a discriminatory auction to sell their debt. It is important to note that some of them are using both mechanisms, depending on the security being auctioned, while others are using pricing rules which are neither uniform nor discriminatory. We investigate the factors which may explain the choice of auction mechanism by a sovereign. We find that countries that have more market oriented economies (as measured by capitalization / GDP) and practice Common law tend to use a uniform price auction. A possible explanation could be that the financial environment in these countries is more attuned to the preferences of public investors, which in the Brenner, Galai and Sade (2007) study seem to be the uniform price mechanism. This attracts wider participation and, as other empirical and experimental papers suggest, results in higher revenues. In other countries where the financial environment is less developed and barriers to the public's participation in the auctions (direct or indirect) may exist, the central planner needs to be more attuned to the preferences of the intermediaries, and if they prefer a discriminatory price auction the central planner will adopt this mechanism.

Our paper belongs to the growing literature on divisible-unit auctions. Recent work in the theory of divisible-unit auctions investigates the trade-offs that the central planner faces in the use of the different mechanisms. ${ }^{4}$ They show that the uniform price

\footnotetext{
${ }^{3}$ We do not have in our sample the following OECD countries: Czech Republic, Denmark, Netherlands, Spain and the Slovak Republic.

${ }^{4}$ See, for example, Wilson (1979), Back and Zender (1993), Ausubel and Cramton (2002) or Wang and Zender (2002) for theoretical evidence on strategic bidding in multi-unit auctions. A survey article on auction theory by Das and Sundaram (1996) discusses the lessons from theoretical models for T-bill auctions, and presents some empirical evidence.
} 
mechanism may result in multiple equilibria and there exist non-cooperative equilibria under the uniform-price format that support collusive outcomes. They also show that these collusive outcomes are not supported by discriminatory auctions. The theory is inconclusive, it does not tell us whether the uniform price auctions will generate higher revenue than the discriminatory price auctions. This remains an empirical issue that our research is trying to contribute to.

Most of the empirical work that compared these two auction mechanisms use an event study approach (e.g. studies of the US experiment). However, this approach suffers from the fact that in these cases it is hard to argue that nothing has changed in the economic environment and in the information set around the event (e.g. the Solomon squeeze has contributed to the US change from discriminatory to uniform).

Additional empirical studies employ structural econometric modeling to compare the alternative auction mechanisms. ${ }^{5}$ These papers use a bidder's optimality condition to recover the distribution of the marginal valuations of the bidders. At its current stage, structural econometric literature does not provide a clear answer with respect to the mechanism choice.

A previous cross country description of auction design issues is Bartolini and Cottarelli (1997). While their paper describes various aspects of the auction mechanism, our paper focuses on the determinants of the choice of the auction pricing rule.

The novelty of our paper is to use a cross section approach and look for explanatory variables that may help to understand the sovereign's decision. While the advantages of learning from common practices are straightforward, the challenge in our empirical investigation is to overcome the fact that countries do not adjust their auction system very frequently. Thus, identifying the important factors that affect the choice of an auction mechanism would be rather rewarding. The results of the survey show that most of the countries in our sample use the discriminatory price mechanism. We find that proxies associated with the development of financial markets play an important role in the auction design mechanism.

The paper is organized as follows. Section 2 looks at the auction practices of different countries. In section 3 we investigate what affects the country's choice by

${ }^{5}$ Hortaçsu (2002), Kastl (2005) 
proposing factors such as the legal system, wealth, "free markets" and other economic factors. Section 4 provides concluding remarks.

\section{Auction Methods Used by Issuers of Government Bonds}

We first investigated the current practices used worldwide at treasury auctions. ${ }^{6}$ Since this information is not available in public databases we had to use our own survey as a method for gathering the information. We have sent a short survey (see appendix A) via e-mails and faxes to central banks and treasuries around the globe ${ }^{7}$. We received answers from 48 countries, listed in Table 1.

Our results (Table 1) indicate that most countries in our sample, 50\%, use a discriminatory price mechanism to issue government debt, about 19\% use a uniform price auction while approximately $19 \%$ use both mechanisms depending on the type of debt instruments being issued. The rest of the countries, about $12 \%$, use a pricing method that is different than the two conventional ones (e.g. Austria).

Interestingly, even among countries with the same currency and relatively similar monetary policy (for example, the EU countries that use the Euro) different types of auctions mechanisms are used to sell each country's debt instruments. Finland, for example, which used a uniform price mechanism, ${ }^{8}$ does not use auctions anymore (although it now considers using them in the future), while France and Germany ${ }^{9}$ currently use a discriminatory price mechanism. We also find that in some countries the mechanism that is being used to sell treasury debt has changed over time (e.g. the US has switched in the 1990s from a discriminatory mechanism to a uniform one, while Mongolia switched from the uniform mechanism to the discriminatory one and Singapore introduced a uniform price mechanism for some of its debt). In about $50 \%$ of our sample, the country employed in the past a different selling mechanism than the one it currently uses. Some countries in our sample use more than one type of pricing rule to sell their

\footnotetext{
${ }^{6}$ Most of the documentation and analysis of pricing rules for financial auctions was done with respect to treasury auctions, mainly due to data availability and the size of these auctions

${ }^{7}$ The survey was sent via e-mail to all the central banks that their e-mails were listed at Bank for International Settlements, international directory and to the treasuries and Central banks that their e-mails/ home pages were listed at the IMF home page. In some cases, when we did not get a response, we used personal contacts to get answers to the survey.

${ }^{8}$ See Keloharju, Nyborg and Rydqvist (2003)

${ }^{9}$ See Rocholl (2004)
} 
debt instruments (e.g. Canada and Brazil). Some use different auction mechanism to issue debt than to buy back debt (e.g USA). ${ }^{10}$ The wide use of different pricing mechanisms also applies to additional financial instruments such as corporate bonds (e.g. in Israel a discriminatory auction is used for Treasury securities while a uniform auction is used for corporate bonds and stocks.)

Given the different practices and the changes introduced by some countries it is clear that research, theoretical, experimental and/or empirical, about auction designs would be of great interest to a variety of issuers, be it governments or corporations. Thus, we also examine the features which make up the profile of a country to see if there are common features that can be associated with one auction design or another.

\section{What may affect the choice of an auction mechanism by a country?}

Given the potential consequences of the optimal mechanism choice on the revenue obtained and the subsequent activity in the secondary markets, it is surprising that we don't find any cross country research about what may affect this choice.

As stated above, the cross section empirical analysis, done for the first time, looks for specific characteristics that affect the mechanism choice. It should be noted that there is no model that provides specific guidelines as to the variables that we should include in the empirical investigation. We have decided to use a set of macro variables that have been used in studying other macro finance issues and seemed to be appropriate in our context.

The first set of variables is related to the risk of the assets that are being auctioned, more specifically the credit risk of the sovereign. The second set of variables is related to the specific characteristics of the country that issues the debt and the characteristics of its financial markets. We have thus examined the recent literature which investigates the different global financial systems, trying to explain their growth and efficiency, as well as other characteristics, by their legal system and other economic and non-economic variables. La Porta et al (1998), Levine (1999) and others, investigate the role of the legal system and argue that legal systems that protect creditors and enforce

\footnotetext{
${ }^{10}$ See Han, Longstaff and Merril (2005) for the description of the US treasury buyback auctions.
} 
contracts are likely to encourage greater financial intermediary development than legal and regulatory systems that impede creditors from gaining access to their claims or that ineffectively enforce contracts. Rajan and Zingales (1998 and 2003) discuss how to measure financial development and suggest that the measures would capture the ease with which any entrepreneur or company or country can raise funds and the confidence with which investors anticipate an adequate return. We follow the approaches described in the above articles and use some of the variables that they use in order to see if some of these proxies may shed some light on the question at hand. In addition, we collected data that includes several indexes that rank different countries according to the easiness of conducting business, the freedom of the economy and the level of corruption. We investigate if the different ranking is an indicator to the different mechanism being employed.

While we would like to have additional variables such as the number of participants in the auction markets and their relative market participation in dollar value, unfortunately this information is not only unavailable to us but is also unavailable to most issuer (central banks and treasuries) since each direct participant in the auction may represent several other participants. ${ }^{11}$

\subsection{Empirical Results}

\subsubsection{Data Sources}

In our empirical investigation of the variables that may explain the auction system chosen by a country we use the following variables:

Type of Auction: $\mathrm{U}=$ uniform, $\mathrm{D}=$ discriminatory, $\mathrm{B}=$ both $\mathrm{O}=$ not using auctions to sell debt instruments.

We collected several potential explanatory variables that describe the asset being sold and the issuer. They were obtained from different sources: ${ }^{12}$
(1) The "World Bank"
(2) Moody's
(3) IFC

\footnotetext{
${ }^{11}$ For a discussion of the limitation of the auction data in the U.S see Fleming (2007)

${ }^{12} \mathrm{We}$ will be happy to provide the full data base for researchers upon request.
} 
(4) Wall Street Journal

(5) Transparency International

For the specific characteristics of the asset that is being auctioned we use default risk.

The rationale for investigating its effect on the mechanism choice is the following; due to the potential negative effect of the winner's "curse" on potential participants and their bidding strategies, riskier debt with higher uncertainty will be auctioned in a uniform price mechanism.

- Moody's Sovereign debt ratings: (Source: Moody's August 2005.) The ratings serve as a proxy for the riskiness of the debt.

- Indebtedness Classification. (Source: World Bank- 2003.) The World Bank classifies countries by their level of indebtedness for the purpose of developing debt management strategies. It uses a three-point scale: severely indebted (S), moderately indebted (M), and less indebted (L). ${ }^{13}$ The Indebtedness classification also serves as proxy for the riskiness of the debt and the level of uncertainty that is associated with it.

Variables that describe the legal, financial structure and economic environment of the countries that issue the debt include:

- Civil (Roman) Law versus Common Law. This variable was proposed by La Porta et al (1998). Common law is associated with countries that have a more liberal economic system, small role for the government like Britain, the United States, Australia, while civil law is associated with economies where the government plays a larger role like France, Germany, Japan. We investigate whether the auction mechanism is associated with the legal system in the country.

- Stock Market Capitalization as Percentage of the GDP. (Source: World Bank - 2003.) Market capitalization is the share price times the number of shares outstanding and is calculated as percentage of the GDP. This variable serves as a proxy for the degree of development of the financial markets. By using this

\footnotetext{
${ }^{13}$ The most severely indebted countries may be eligible for debt relief under special programs, such as the HIPC Debt Initiative. Indebted countries may also apply to the Paris and London Clubs for renegotiation of obligations to public and private creditors. In 2003, countries with a present value of debt service greater than 220 percent of exports or 80 percent of GNI were classified as severely indebted, countries that were not severely indebted but whose present value of debt service exceeded 132 percent of exports or 48 percent of GNI were classified as moderately indebted, and countries that did not fall into either group were classified as less indebted.
} 
variable we test if there is a relationship between the level of the development of financial markets and the auction mechanism

- GDP. -(Source: World bank - 2003.) GDP is measured in current US dollars. GDP serves as proxy for country size.

We also use several indexes that rank the level of competitiveness, economic freedom and corruption in the country

- The Ease of Doing Business 2006 index. (source: IFC). This index ranks countries on their ease of doing business, from $1-175$. A high ranking on the ease of doing business index means the regulatory environment is conducive to the operation of business. This index averages the country's percentile rankings on 10 topics, made up of a variety of indicators.

- The CPI Corruption Index 2005. (Source: Transparency International) aims to measure the overall extent of corruption (frequency and/or size of bribes) in the public and political sectors. The index ranks countries from 1 to 158 .

- The Index of Economic Freedom 2006, (Source: the Heritage Foundation/Wall Street Journal) The index uses 50 independent variables divided into 10 broad factors of economic freedom to rank 161 countries.

\subsubsection{Empirical Findings - A Univariate Investigation}

We divided our sample into 3 categories according to the pricing mechanism, those that use the discriminatory ( 24 countries), those that use the uniform ( 9 countries) and those that use both mechanisms (9 countries). Table 2 provides the means and medians of these variables with respect to the auction mechanism being used.

First, we find that countries that use a discriminatory price mechanism have on average significantly lower capitalization to GDP ratio compared with countries that use a uniform price mechanism $(\mathrm{P}=0.03)^{14}$ and countries that use both mechanisms $(\mathrm{P}=0.04)$. There is no significant difference in the average of this ratio between countries that use both mechanism and those that use the uniform price mechanism.

\footnotetext{
${ }^{14}$ Equal variance is not assumed in all the t-tests described in this section.
} 
Second, we find that the type of law practiced in countries that use a discriminatory price mechanism is significantly $(\mathrm{p}=0.038)$ different than the law system in countries that use a uniform price mechanism. Specifically we find that countries that use a discriminatory price mechanism tend to be countries with a civil law system. ${ }^{15}$

Third, we do not find GDP to be significantly different, on average, between countries that use the discriminatory mechanism and countries that use the uniform price mechanism.

Fourth, although we find that the frequency of Indebtedness Classification is higher for countries that use a discriminatory price mechanism compared with those that use a uniform price mechanism, the difference is only marginally significant.

Fifth, we find, using a standard non parametric test, that the ranking of Ease of Doing Business Index for countries that use a uniform price mechanism is significantly better than those that use a discriminatory price mechanism.

Though we find that a lower Corruption Index level and a higher level of Economic Freedom Index is associated with countries that employ a uniform price mechanism compared with the discriminatory price mechanism, these differences are not statistically significant.

In summary, the univariate investigation indicates that variables that are associated with development of financial markets: capitalization to GDP, ease of doing business and the type of law employed are statistically significant.

\subsubsection{A Multivariate Investigation - Multinomial Logit and Discriminatory Analysis}

In order to estimate which variables affect the mechanism choice we conducted a multinomial regression analysis. Our dependent variable consists of 4 groups and the categories are not ordered. Hence, a Multinomial Logistic regression is the natural statistical model to use. ${ }^{16}$

\footnotetext{
${ }^{15}$ The same applies to the difference between countries that use a discriminatory mechanism vs. countries that use both types of mechanisms.

${ }^{16}$ Multinomial logit models are a straightforward extension of logistic models. While the logit models are used for binary independent variables where the logistic distribution is used to derive the probability, the generalization to more than two alternatives (here we have 4) is referred to as the multinomial logit models.
} 
The Multinomial Logit model has the form:

$$
\mathrm{b} i=\frac{\exp (\beta, j x)}{\sum_{j} \exp \left(\beta_{j} \mathrm{x}\right)} \text { for } j=1, \ldots, \mathrm{k}+1
$$

Where $\beta$ s serve as the coefficients and $\mathrm{p}$ is the probability.

Our dependent variable was classified into 4 categories as follows:

Countries that use the uniform price mechanism $=1$

Countries that use the discriminatory price mechanism $=2$

Countries that use both mechanisms $=3$

Countries that use other types of auctions $=4$

We estimated 4 different models with a different set of independent variables. In Table 3 we present the values of the coefficients and the statistical significance only for the comparison between the uniform price mechanism and the discriminatory price mechanism. When using a Multinomial Logit regression, one category of the dependent variable is chosen as the reference variable. In our investigation the discriminatory price mechanism is the reference group.

Our main finding is that capitalization/GDP is positively and significantly correlated with the choice of a uniform price mechanism, rather than the discriminatory price mechanism. The dummy variable for civil law vs. common law is significantly correlated with the bidding system (see Table 3.) When the two variables are used together to estimate the mechanism choice, only the capitalization as percentage of the GDP remains significant. This could be due to multicolinearity; the Pearson correlation between these two variables; legal system and Capitalization/GDP ratio is --0.354 which is significant. (See Table 4.) Neither the GDP by itself nor the Dummy for Indebtedness Classification are significantly correlated with the mechanism choice. ${ }^{17}$

It is important to note that countries do not change their auction mechanism frequently and we have conducted the survey in a specific point in time. Given the sample size this may somewhat affect the explanatory power of our model since we may be capturing some countries that were in transition between auction mechanisms. Yet,

\footnotetext{
${ }^{17} \mathrm{We}$ also examined the choice between using both mechanisms vs. using only the discriminatory price mechanism. The only variable that is significant and negatively correlated with the decision to use "both" mechanisms compared to using the discriminatory mechanism is the dummy variable for civil law. All the other variables examined in this section are insignificant.
} 
even with this statistical noise the Capitalization/GDP variable turns out to be significant and explains about $10 \%$ of the mechanism choice.

For robustness we also conducted a discriminatory analysis on the countries that use a uniform price mechanism versus those that use a discriminatory price mechanism. The discriminatory analysis is used in the literature to classify cases into categorical dependence. The results that we obtain using this procedure are consistent with our multinomial logit results. We find that we can correctly classify $82 \%$ of the observations by using only the Capitalization/GDP variable, moreover adding other variables from our list does not significantly improve our ability to classify. The Wilks' Lambda test is significance at 0.007

Our results suggest that the country characteristics play an important role in the mechanism choice. Interestingly, this is consistent with the paper of Doidge, Karolyi and Stulz, (2006) who found that the country characteristics are more important than firm characteristics with respect to corporate governance.

Why does the financial markets development factor play such an important role in the auction design decision of the issuer? Why countries with less developed financial markets choose the discriminatory auction? Our conjecture is related to the bargaining power of the different financial players in the market.

In many countries, because of regulations, financial market development or barrier to entry for investors, the issuer can not rely on sufficient (at a desirable minimum price) direct investor participation and needs the help of the intermediaries in order to sell the issue. If the intermediaries prefer discriminatory price mechanism, then the issuer has an incentive to use this pricing mechanism. ${ }^{18}$

Why would dealers/intermediaries prefer a discriminatory mechanism? One possible explanation is that this mechanism does not result in one known equal price to all investors, which helps them to sell it at a higher price in the secondary market. Another possible explanation relates to Friedman's argument, that the discriminatory mechanism reduces the number of potential bidders and hence the number of potential competitors. Another explanation is related to the price paid by the bidders. Sade, Schnitzlein and Zender (2006) experimental work shows that under pre-determined

\footnotetext{
${ }^{18}$ For part of our sample we were able to collect the total size of government debt and indeed those countries that use a discriminatory price mechanism have on average larger government debt to GDP ratio.
} 
number of participants in the discriminatory mechanism, on average, the participants collude more and pay lower prices.

On the other hand in countries with well developed financial markets, the intermediaries have less bargaining power in setting the auction mechanism choice since the central player can rely on the public participation. A supportive argument, consistent with this conjecture, is made by Brenner, Galai and Sade (2007) in an experimental study. They show that when investors are given the choice between a uniform auction and a discriminatory one, they prefer to participate in a uniform auction, and are willing to pay higher prices. It is suggested that a possible reason for such a preference is that uniform auctions are perceived as "fair" and transparent by the participants. ${ }^{19}$

Given the intermediaries assumed preferences on one hand, the investors/public assumed preferences on the other hand and the issuer's objective, it is clear why the bargaining power between the three different stakeholders may affect the auction's mechanism choice. ${ }^{20}$

\footnotetext{
${ }^{19}$ In addition see Garbade (2004) for the description of the 1959 testimony by Robert Anderson, the Secretary of the Treasury who suggested that small banks, corporations, and individuals do not have the "professional capacity" to bid at the discriminatory price mechanism.

${ }^{20}$ It could be argued that the main consideration in choosing a discriminatory auction in the US Treasury buy back program is the dealers bargaining power.
} 


\section{Summary and Conclusions}

In issuing financial assets governments and corporations face a major decision; what is the optimal offering process to sell their debt or equity? Most governments and some corporations use an auction mechanism. There are basically two common types of auctions for financial assets: the uniform price auction and the discriminatory price auction. The existing theoretical and empirical work is ambivalent about the method that issuers should choose.

We find that most countries use the discriminatory method, and fewer use the uniform one. However, an important factor that is associated with the uniform price mechanism is the "market oriented economy". We also find that countries that use the uniform price mechanism tend to be "common law" countries and have on average a more favorable ranking for "easiness of doing business", economic freedom and the level of corruption. Using multinomial analysis, we find that Capitalization/GDP is significantly correlated with the mechanism choice. A discriminatory analysis provides similar results.

So why do we find so many countries using the discriminatory pricing method? Our conjecture is that the financial markets in many of these countries are dominated by a few large financial intermediaries and it is in their interest, paying lower prices, to have a discriminatory price mechanism rather than a uniform price mechanism. These few institutions are better informed than the rest of the public simply because they hold a large portion of the potential bids either as proprietary bidders or as agents for other bidders. This conjecture is supported by our tests that show that the discriminatory method is used more in countries which have less developed financial markets ${ }^{21}$.

\footnotetext{
${ }^{21}$ An additional explanation for the origin of using a given rule or method has to do with the evolution of financial markets around the globe. Since the development of financial markets around the globe has, by and large, lagged behind the U.S many countries have just followed the U.S example without questioning its rationale and whether it is appropriate and fits the market structure of that country.
} 


\section{Bibliography}

Ausubel, L., and P. Cramton, 2002, "Demand Reduction and Inefficiency in Multi-Unit Auctions," University of Maryland working paper.

Back, K., and J.F. Zender, 1993, “Auctions of Divisible Goods: On the Rationale for the Treasury Experiment," Review of Financial Studies, 6, 733-764.

Back K and J.F. Zender, 2001, "Auctions of Divisible Goods with Endogenous Supply", Economics Letters, 73, 29-34

Bartolini L and C. and Cottarelli, 1997, "Treasury Bill Auctions: Issues and Uses" in Macroeconomics Dimensions of Public Finance, Essays in honor of Vito Tanzi, edited by Blejer and Ter-Minassian, Routledge, 267-336

Bikchandani, S., and C. Huang, 1993, "Auctions with Resale Markets: An Explanatory Model of Treasury Bill Markets", Review of Financial Studies, 6, 311-339.

Brenner M, Galai D and O. Sade, 2007, " Endogenous Bidder Preferences in Divisible Good Auction: Discriminatory versus Uniform " Working Paper

Bulow, J I. and P. D. Klemperer. 1996, "Auctions vs Negotiations," American Economic Review, 86 pp. 180-94

Cammack, E., 1991, Evidence on Bidding Strategies and the Information in Treasury Bill Auctions", Journal of Political Economy, 99(1), February, 100-130

Cox C. J, Smith L. V and W. M. James, 1985, "Expected Revenue in Discriminative and Uniform Price Sealed Bid Auction", Research in Experimental Economics a Research annual, Editor Smith L. Vernon, volume 3, JAI Press INC, 183-232.

Das, S. R., and R. K. Sundaram 1996, “Auction Theory: A Survey with Applications to Treasury Markets", Financial Markets, Institutions and Instruments, V.5, N.5, pp. 1-36

Doidge, Karolyi and Stulz, 2006, "Why Do Countries Matter So Much for Corporate Governance?" Journal of Financial Economics, forthcoming

Engelbrecht-Wiggans R, List A. J, and D H. Reiley, 2006, "Demand Reduction in Multiunit Auctions with Varying Numbers of Bidders: Theory and Field Experiments.", International Economic Review 47 (1), 203-231..

Feldman, R. A and V. R. Reinhart, 1995, "Flexible Estimation of Demand Schedules and Revenue under Different Auction Formats”, IMF- Working Paper No. 95/116. 
Fleming J.M, (2007), "Who Buys Treasury Securities at Auction?" Federal Reserve Bank of New York Current Issues in Economics and Finance, Vol. 13, No. 1, January 2007

Friedman, M. 1960, A Program for Monetary Stability, Fordham University Press, New York.

Garbade K , 2004, " The institutionalization of treasury note and bond auctions, 197075", Federal Reserve Bank of New York Economic Policy Review, May, 29-45

Goldreich D, 2007 "Underpricing in Discriminatory and Uniform-Price Treasury Auctions," Journal of Financial and Quantitative Analysis Vol. 42, No. 2, June, 443466.

Goswami, G., T. Noe, and M. Rebello, 1996, "Collusion in Uniform-Price Auctions: Experimental Evidence and Implications for Treasury Auctions," Review of Financial Studies, 9, 757-785.

Han B, F.A Longstaff and C. Merrill, 2005, "The "Cherry- Picking" Option in The U.S Treasury Buyback Auctions" forthcoming, Journal of Finance

Hortaçsu, A., 2002, "Mechanism Choice and Strategic Bidding in Divisible Good Auctions: An Empirical Analysis of the Turkish Treasury Auction Market," Working Paper

Ivanova-Stenzel Radosveta and Salmon C. Timothy, 2004, "Bidder Preferences Among Auction Institutions", Economic Inquiry, 42, 2, 223-236

Jagadeesh N, 1993, Treasury Auction Bids and the Salomon Squeeze, Journal of Finance, September, 1403-1419

Kagel, H. J., 1995, "Auctions: A Survey of Experimental Research", The Handbook of Experimental Economics edited by Kagel H. John and Roth E. Alvin, 501-585.

Kastl, J.,2005, "Discrete Bids and Empirical Inference in Divisible Good Auctions", working paper 
Keloharju, M., K. Nyborg, and K. Rydqvist, 2005, "Strategic Behavior and Underpricing in Uniform-Price Auctions: Evidence from Finnish Treasury Auctions," Journal of Finance 60, (4), 1865-1902..

La Porta R, Lopez-de-Silanes F, Shleifer A and R. W. Vishny, 1998, "Law and Finance", Journal of Political Economy 106.6 (Dec): 1113-1155

Levin, D. and Smith, J.L .,1994, "Equilibrium in Auctions with Entry" American Economic Review, 84, 585-99.

Levine, R. 1999, "Law, Finance, and Economic Growth" Journal of Financial Intermediation 8, 8-35

Malvey, P. F., C. M. Archibald, and S. T. Flynn, 1995, "Uniform-Price Auctions: Evaluation of the Treasury Experience:, Office of Market Finance, U.S. Treasury

Malvey, P. F., and C. M. Archibald, 1998, "Uniform-Price Auctions: Update of the Treasury Experience", Office of Market Finance, U.S. Treasury

McAfee R. P, 1993, “Mechanism Design by Competing Sellers”, Econometrica, 61(6) $1281-1312$

Miller J. G. and R. C., Plott 1985, "Revenue Generating Properties of Sealed-Bid Auctions; An Experiment Analysis of One-Price and Discriminative Process", Research in Experimental Economics a Research annual, Editor Smith L. Vernon, volume 3, JAI Press INC, 159-182.

Nyborg, K., and Sundaresan, S., 1996, "Discriminatory versus Uniform Treasury Auctions: Evidence from When-Issued Transactions," Journal of Financial Economics, Vol. 42,

Rajan, R., and Zingales, L., 1998, "Financial Dependence and Growth". American Economic Review 88, 559-586.

Rajan R.G., and L. Zingales, 2003, "The great reversals: the politics of financial development in the twentieth century", Journal of Financial Economics 69, 5-50

Rocholl J., 2004, Discriminatory Auctions in which the Seller has Discretion, Working Paper 
Sade O., Schnitzlein and J. F. Zender, 2006, "Competition and Cooperation in Divisible Good Auctions: An Experimental Examination” Review of Financial Studies 19(1), 195235

Salavirta E and K. Taipalus ,2003, Money and Capital Markets, Finish Financial Markets 2002, Heikki Koskenkylä (ed), Bank of Finland Studies A:105, 37- 65

Smith L. V., 1967, "Experimental Studies of Discrimination Versus Competition in Sealed-Bid Auction Markets, Journal of Business, 40, 56-84.

Tenorio, R., 1993, "Revenue-Equivalence and Bidding Behavior in a Multi-Unit Auction Market: An Empirical Analysis" Review of Economics and Statistics vol.75 pp.302-314.

Umlauf, S., 1993, “An Empirical Study of the Mexican Treasury Bill Auction,” Journal of Financial Economics, 33, 313-340.

Wilson, R., 1979, “Auctions of Shares,” Quarterly Journal of Economics, 93, 675-698. 


\section{Table 1}

\section{Survey Answers Regarding the Type of Auctions Used to sell Government Debt in Different Countries around the World as of April - October 2005}

The Table describes the answers to a survey that were obtained from treasuries and central bank during 2005 and 2006 regarding the auction mechanism being used to sell the country's debt. UPA is Uniform Price Mechanism and DPA is Discriminatory Price Auction. The questions are presented in Appendix A.

\begin{tabular}{|c|c|c|c|c|}
\hline $\begin{array}{l}\text { Name of the } \\
\text { Country }\end{array}$ & $\begin{array}{l}\text { Using } \\
\text { Auctions to } \\
\text { Sell Govern } \\
\text { Debt }\end{array}$ & $\begin{array}{l}\text { Type of } \\
\text { Auction }\end{array}$ & $\begin{array}{l}\text { Different Selling } \\
\text { Mechanism Used } \\
\text { in the Past }\end{array}$ & $\begin{array}{l}\text { Discretionary } \\
\text { Effective } \\
\text { Supply }\end{array}$ \\
\hline Argentina & $\sqrt{ }$ & UPA & No & No \\
\hline Australia & $\sqrt{ }$ & UPA & $\begin{array}{c}\text { Yes } \\
\text { Tap mechanism }\end{array}$ & $\begin{array}{l}\text { No, although } \\
\text { the Treasurer } \\
\text { has the right to } \\
\text { cancel a tender }\end{array}$ \\
\hline Austria & $\sqrt{ }$ & $\begin{array}{l}\text { Multiple Price - } \\
\text { the coupon is } \\
\text { calculated on the } \\
\text { basis of the } \\
\text { weighted average } \\
\text { of the accepted } \\
\text { yields and an } \\
\text { issue price which } \\
\text { shall be as close } \\
\text { to par as } \\
\text { possible, after } \\
\text { considering the } \\
\text { maturity- } \\
\text { dependent } \\
\text { commission. }\end{array}$ & $\begin{array}{c}\text { issued bonds under } \\
\text { several programs } \\
\text { (DIP, EMTN- } \\
\text { Program, AUD- } \\
\text { Program for long } \\
\text { term bonds (EUR } \\
\text { and FX) and ATB- } \\
\text { Program for money } \\
\text { market } \\
\text { instruments) by } \\
\text { selling them to a } \\
\text { group of dealers }\end{array}$ & $\begin{array}{l}\text { In case the } \\
\text { book shows } \\
\text { huge demand } \\
\text { the Republic is } \\
\text { allowed to } \\
\text { increase the } \\
\text { issue amount }\end{array}$ \\
\hline Bangladesh & $\sqrt{ }$ & DPA & Yes & Yes \\
\hline Belgium & $\begin{array}{c}\sqrt{ } \\
\text { Only the } \\
\text { launching of } \\
\text { new OLO } \\
\text { benchmarks } \\
\text { is done by } \\
\text { syndication }\end{array}$ & DPA & $\begin{array}{c}\text { Yes } \\
\text { Underwriting by a } \\
\text { consortium of } \\
\text { banks (prior the } \\
\text { adoption of the } \\
\text { primary dealers } \\
\text { system in 1989) }\end{array}$ & $\begin{array}{c}\text { The Treasury } \\
\text { only announces } \\
\text { a target } \\
\text { issuance range } \\
\text { before the } \\
\text { auction. } \\
\text { Primary }\end{array}$ \\
\hline
\end{tabular}




\begin{tabular}{|c|c|c|c|c|}
\hline & & & & $\begin{array}{l}\text { dealers have } \\
\text { the right to } \\
\text { submit non } \\
\text { competitive } \\
\text { subscriptions } \\
\text { after the } \\
\text { auction, as a } \\
\text { function of } \\
\text { their successful } \\
\text { bids. }\end{array}$ \\
\hline Brazil & $\sqrt{ }$ & $\begin{array}{c}\text { Both UPA and } \\
\text { DPA }\end{array}$ & No & No \\
\hline Cambodia & $\sqrt{ }$ & DPA & No & $\begin{array}{c}\text { Yes } \\
\text { But with } \\
\text { budget } \\
\text { considerations }\end{array}$ \\
\hline Canada & $\sqrt{ }$ & $\begin{array}{c}\text { Primary: DPA, } \\
\text { yet Real return } \\
\text { bonds are } \\
\text { auctioned via } \\
\text { UPA }\end{array}$ & $\begin{array}{c}\text { Yes } \\
\text { syndicated } \\
\text { issuance }\end{array}$ & $\begin{array}{c}\text { Yes } \\
\text { (Not in use) }\end{array}$ \\
\hline Colombia & $\sqrt{ }$ & UPA & $\begin{array}{l}\text { Yes } \\
\text { Some securities } \\
\text { are placed directly } \\
\text { by the Treasury } \\
\text { Department. In the } \\
\text { past inflation } \\
\text { linked bonds (only } \\
\text { the coupons were } \\
\text { indexed) were } \\
\text { placed directly by } \\
\text { the Treasury }\end{array}$ & Yes \\
\hline Cyprus & $\sqrt{ }$ & DPA & Yes & $\begin{array}{c}\text { Yes } \\
\text { Can reduce the } \\
\text { amount } \\
\text { announced } \\
\end{array}$ \\
\hline Ecuador & $\sqrt{ }$ & DPA & No & No \\
\hline Fiji & $\sqrt{ }$ & Tender & $\begin{array}{l}\text { Yes } \\
\text { UPA }\end{array}$ & Yes \\
\hline Finland & $\begin{array}{c}\text { No } \\
\text { Use } \\
\text { syndicated }\end{array}$ & ${ }$ & Auction - UPA & Yes \\
\hline
\end{tabular}




\begin{tabular}{|c|c|c|c|c|}
\hline & issue & & & \\
\hline France & $\sqrt{ }$ & DPA & $\begin{array}{l}\text { No (however, } \\
\text { new/innovative } \\
\text { products can be } \\
\text { issued by } \\
\text { syndication) }\end{array}$ & No \\
\hline Germany & $\begin{array}{c}\sqrt{ } \\
\text { Except for } \\
\text { US-Dollar- } \\
\text { Bond, which } \\
\text { Germany } \\
\text { issued for the } \\
\text { first time in } \\
\text { May 2005, } \\
\text { using a } \\
\text { consortium }\end{array}$ & DPA & $\begin{array}{c}\text { Yes } \\
\text { until } \\
1997 \text { (consortium, } \\
\text { led by the } \\
\text { Deutsche } \\
\text { Bundesbank, i.e. } \\
\text { the central bank) }\end{array}$ & Yes \\
\hline Ghana & $\sqrt{ }$ & DPA and UPA & No & No \\
\hline Greece & $\sqrt{ }$ & $\begin{array}{l}\text { Mainly DPA, in } \\
\text { addition, } \\
\text { syndications }\end{array}$ & $\begin{array}{c}\text { Yes } \\
\text { syndicated } \\
\text { issuance }\end{array}$ & $\begin{array}{l}\text { Yes } \\
\text { If prices given } \\
\text { for } 80 \% \text { of the } \\
\text { amount diverge } \\
\text { significantly } \\
\text { from those } \\
\text { given for the } \\
\text { remaining } \\
20 \% \text {, the issuer } \\
\text { has the right to } \\
\text { accept only } \\
80 \% \text { of the } \\
\text { auction } \\
\text { amount. }\end{array}$ \\
\hline Hungary & $\sqrt{ }$ & DPA & No & No \\
\hline Ireland & $\sqrt{ }$ & $\begin{array}{c}\text { Competitive } \\
\text { Auction - Best } \\
\text { Price using the } \\
\text { Bloomberg } \\
\text { Auction System }\end{array}$ & No & Yes \\
\hline Israel & $\sqrt{ }$ & DPA & & $\begin{array}{c}\text { Yes } \\
\text { From recently }\end{array}$ \\
\hline Italy & $\sqrt{ }$ & $\begin{array}{l}\text { UPA for Bonds } \\
\text { DPA for T-Bills }\end{array}$ & No & $\begin{array}{l}\text { For index- } \\
\text { linked bonds, } \\
\text { the Treasury }\end{array}$ \\
\hline
\end{tabular}




\begin{tabular}{|c|c|c|c|c|}
\hline & & & & $\begin{array}{c}\text { can select a } \\
\text { minimal } \\
\text { acceptable } \\
\text { price }\end{array}$ \\
\hline Jamaica & $\begin{array}{c}\sqrt{ } \\
\text { Yet, the main } \\
\text { mechanism is } \\
\text { Direct } \\
\text { Placement at } \\
\text { a pre- } \\
\text { determined } \\
\text { coupon }\end{array}$ & DPA & No & No \\
\hline Japan & $\sqrt{ }$ & $\begin{array}{l}\text { Competitive } \\
\text { price auction, } \\
\text { noncompetitive } \\
\text { auction, Dutch- } \\
\text { style yield } \\
\text { auction. }\end{array}$ & Yes & Not Relevant \\
\hline Korea & $\sqrt{ }$ & Uniform Price & Yes- DPA & $\begin{array}{c}\text { Yes, but } \\
\text { strictly } \\
\text { refrained from } \\
\text { using it }\end{array}$ \\
\hline Latvia & $\sqrt{ }$ & $\begin{array}{l}\text { DPA where the } \\
80 \% \text { of debt is } \\
\text { offered at the } \\
\text { Bank of Latvia } \\
\text { the next day the } \\
20 \% \text { of debt is } \\
\text { offered at the } \\
\text { Latvian Central } \\
\text { Depository }\end{array}$ & $\begin{array}{c}\text { Yes } \\
\text { DPA where the } \\
100 \% \text { of debt were } \\
\text { offered at the Bank } \\
\text { of Latvia }\end{array}$ & Yes \\
\hline Lithuania & $\sqrt{ }$ & DPA & No & Yes \\
\hline Luxembourg & $\begin{array}{c}\text { No } \\
\text { Due to a long } \\
\text { history of } \\
\text { budgetary } \\
\text { surpluses } \\
\end{array}$ & ---- & No & $\begin{array}{l}--- \\
\end{array}$ \\
\hline Macedonia & $\sqrt{ }$ & DPA & No & No \\
\hline Malta & $\sqrt{ }$ & $\begin{array}{c}\text { DPA } \\
\text { (known as } \\
\text { American }\end{array}$ & $\begin{array}{l}\text { Yes } \\
\text { Issued in the past at } \\
\text { par without the }\end{array}$ & $\begin{array}{c}\text { Yes for T-bills, } \\
\text { No for Malta } \\
\text { Government }\end{array}$ \\
\hline
\end{tabular}




\begin{tabular}{|c|c|c|c|c|}
\hline & & Auction) & $\begin{array}{c}\text { possibility of } \\
\text { investors bidding at } \\
\text { a different price }\end{array}$ & Stocks \\
\hline Mauritius & $\sqrt{ }$ & DPA & No & No \\
\hline Mexico & $\sqrt{ }$ & $\begin{array}{c}\text { Both DPA and } \\
\text { UPA }\end{array}$ & $\begin{array}{c}\text { Yes } \\
\text { Tap with a fixed } \\
\text { rate }\end{array}$ & Yes \\
\hline Mongolia & $\sqrt{ }$ & DPA & $\begin{array}{c}\text { Yes } \\
\text { Used in the past } \\
\text { Uniform price } \\
\text { mechanism }\end{array}$ & Yes \\
\hline Norway & $\sqrt{ }$ & UPA & $\begin{array}{l}\text { Yes } \\
\text { DPA }\end{array}$ & No \\
\hline New Zealand & $\sqrt{ }$ & $\begin{array}{c}\text { DPA } \\
\text { for nominal } \\
\text { bonds and } \\
\text { Treasury bills }\end{array}$ & $\begin{array}{l}\text { UPA for inflation- } \\
\text { linked bonds } \\
\text { (Not auctioned } \\
\text { recently.) }\end{array}$ & $\begin{array}{l}\text { Yes } \\
\text { Reserve the } \\
\text { right to issue } \\
\text { less than the } \\
\text { full amount of } \\
\text { securities } \\
\text { offered in any } \\
\text { auction. }\end{array}$ \\
\hline Panama & $\sqrt{ }$ & DPA & No & Yes \\
\hline Poland & $\sqrt{ }$ & $\begin{array}{c}\text { DPA (known as } \\
\text { American } \\
\text { Auction) }\end{array}$ & ----- & Yes \\
\hline Portugal & $\begin{array}{c}\sqrt{ } \\
\text { Portuguese } \\
\text { government } \\
\text { bonds are } \\
\text { launched via } \\
\text { syndicate and } \\
\text { subsequently } \\
\text { reopened } \\
\text { through } \\
\text { auction }\end{array}$ & DPA & ----- & Yes \\
\hline Sierra Leon & $\sqrt{ }$ & $\begin{array}{l}\text { UPA for Bearer } \\
\text { Bonds and DPA } \\
\text { for Treasury Bills }\end{array}$ & $\begin{array}{c}\text { Yes } \\
\text { Fixed Interest Rate }\end{array}$ & $\begin{array}{c}\text { Yes } \\
+/-30 \% \text { of the } \\
\text { offered amount }\end{array}$ \\
\hline Singapore & $\sqrt{ }$ & $\begin{array}{c}\text { UPA for } \\
\text { Government } \\
\text { Bonds and } \\
\text { Discriminatory }\end{array}$ & $\begin{array}{c}\text { Yes } \\
\text { MAS previously } \\
\text { have used multiple } \\
\text { price auction for }\end{array}$ & No \\
\hline
\end{tabular}




\begin{tabular}{|c|c|c|c|c|}
\hline & & $\begin{array}{c}\text { price auction for } \\
\text { T-bills }\end{array}$ & $\begin{array}{l}\text { both Government } \\
\text { Bonds and T-bill }\end{array}$ & \\
\hline Slovenia & $\sqrt{ }$ & $\begin{array}{l}\text { UPA for short- } \\
\text { term securities } \\
\text { (T-bills), DPA } \\
\text { for long-term } \\
\text { bonds }\end{array}$ & No & \\
\hline $\begin{array}{l}\text { Solomon } \\
\text { Islands }\end{array}$ & $\sqrt{ }$ & DPA & Yes & No \\
\hline Sweden & $\sqrt{ }$ & DPA & No & Yes \\
\hline Switzerland & $\sqrt{ }$ & UPA & Yes & Yes \\
\hline $\begin{array}{c}\text { Trinidad and } \\
\text { Tobago }\end{array}$ & $\sqrt{ }$ & UPA & $\begin{array}{c}\text { Yes } \\
\text { Tendering by } \\
\text { Underwrites }\end{array}$ & No \\
\hline Turkey & $\sqrt{ }$ & DPA & $\begin{array}{l}\text { Yes } \\
\text { UPA }\end{array}$ & Yes \\
\hline $\begin{array}{c}\text { United } \\
\text { Kingdom }\end{array}$ & $\sqrt{ }$ & $\begin{array}{l}\text { UPA for index- } \\
\text { linked gilt } \\
\text { auctions and } \\
\text { DPA for } \\
\text { conventional gilt } \\
\text { auctions }\end{array}$ & $\begin{array}{c}\text { Yes } \\
\text { Until the early } \\
\text { 1990s gilts were } \\
\text { usually issued by } \\
\text { "tap" }\end{array}$ & $\begin{array}{l}\text { Yes } \\
\text { The DMO } \\
\text { reserves the } \\
\text { right not to } \\
\text { allot all the } \\
\text { stock on offer } \\
\text { at a gilt auction } \\
\text { in exceptional } \\
\text { circumstances } \\
\text { where it judges } \\
\text { bids to be at an } \\
\text { unacceptably } \\
\text { deep discount }\end{array}$ \\
\hline U.S.A & $\sqrt{ }$ & UPA & DA & $\begin{array}{c}\text { Yes } \\
\text { Yet, was not in } \\
\text { use }\end{array}$ \\
\hline Venezuela & $\sqrt{ }$ & DPA & No & No \\
\hline
\end{tabular}




\section{Table 2}

\section{Descriptive Statistics}

This table describes the descriptive statistics of the countries according to the auction mechanism employed by them. Indebtedness Classification. (Source: World Bank2003.) The World Bank classifies countries by their level of indebtedness for the purpose of developing debt management strategies. It uses a three-point scale: severely indebted (S), moderately indebted (M), and less indebted (L). The Indebtness classification also serves as proxy for the riskiness of the country. Civil (Roman) Law versus Common Law. This variable was proposed by La Porta et al (1998). We try to see whether the auction mechanism is associated with the legal system in a country. Stock Market Capitalization as Percentage of the GDP. (Source: World Bank - 2003.) Market capitalization is the share price times the number of shares outstanding and is calculated as percentage of the GDP.GDP. - (Source: World bank - 2003.) GDP is measured in current US dollars. Ease of Doing Business 2006.(source: IFC - published in 2005) The ease of doing business index ranks economies from 1 to 155 .

\begin{tabular}{|c|c|c|c|}
\hline & $\begin{array}{l}\text { Discriminatory } \\
(\mathrm{N}=24)\end{array}$ & $\begin{array}{l}\text { Uniform } \\
(\mathrm{N}=9)\end{array}$ & $\begin{array}{c}\text { Both } \\
(\mathrm{N}=9)\end{array}$ \\
\hline$\%$ of civil law & $83 \%^{22}$ & $44 \%$ & $43 \%$ \\
\hline $\begin{array}{l}\text { Avg Stock Market } \\
\text { Capitalization \% of } \\
\text { GDP }\end{array}$ & $\begin{array}{c}38 \%{ }^{23} \\
(\mathrm{std}=32 \%)\end{array}$ & $\begin{array}{c}97 \% \\
(\mathrm{std}=69 \%)\end{array}$ & $\begin{array}{c}54 \% \\
(\mathrm{std}=42 \%)\end{array}$ \\
\hline $\begin{array}{l}\text { Median Stock Market } \\
\text { Capitalization \% of } \\
\text { GDP }\end{array}$ & $28 \%{ }^{24}$ & $101 \%$ & $42 \%$ \\
\hline Avg GDP & $\begin{array}{c}2.49 \mathrm{E}+11 \\
(\mathrm{std}=5.80 \mathrm{E}+11)\end{array}$ & $\begin{array}{l}1.43 \mathrm{E}+12 \\
(\mathrm{std}= \\
3.56 \mathrm{E}+12)\end{array}$ & $\begin{array}{l}5.54 \mathrm{E}+11 \\
(\mathrm{std}= \\
6.36 \mathrm{E}+11)\end{array}$ \\
\hline $\begin{array}{l}\text { Percentage of } \\
\text { Indebtedness } \\
\text { Classification }\end{array}$ & $67 \%{ }^{25}$ & $33 \%$ & $44 \%$ \\
\hline $\begin{array}{c}\text { Avg Ranking of Ease of } \\
\text { Doing Business }\end{array}$ & $56^{26}$ & $25^{27}$ & 62 \\
\hline
\end{tabular}

\footnotetext{
${ }^{22}$ Based on 23 observations since we do not have the classification for the source of law of Solomon Islands.

${ }^{23}$ Based on 19 observations since data was not available for Cambodia, Macedonia, Malta, Cyprus and Solomon Islands.

${ }^{24}$ Based on 19 observations since data was not available for Cambodia, Macedonia, Malta, Cyprus and Solomon Islands

${ }^{25}$ Based on 21 observations since data was not available for Malta, Cyprus and Solomon Islands
} 


\begin{tabular}{|c|c|c|c|}
\hline $\begin{array}{c}\text { Median Ranking of } \\
\text { Ease of Doing Business }\end{array}$ & $52^{28}$ & $11^{29}$ & 70 \\
\hline $\begin{array}{c}\text { Avg Ranking of } \\
\text { Corruption Index }\end{array}$ & $61^{30}$ & 33 & 44 \\
\hline $\begin{array}{c}\text { Median Ranking of } \\
\text { Corruption Index }\end{array}$ & $51^{31}$ & 17 & 40 \\
\hline $\begin{array}{c}\text { Average ranking of } \\
\text { Economics Freedom } \\
\text { Index }\end{array}$ & $55^{32}$ & 39 & 51 \\
\hline $\begin{array}{c}\text { Median Ranking Of } \\
\text { Economics Freedom } \\
\text { Index }\end{array}$ & $44^{33}$ & 30 & 42 \\
\hline
\end{tabular}

\footnotetext{
${ }^{26}$ Based on 22 observations since data was not available for Malta and Cyprus.

${ }^{27}$ Based on 8 observations since data was not available for Trinidad and Tobago.

${ }^{28}$ Based on 22 observations since data was not available for Malta and Cyprus.

${ }^{29}$ Based on 8 observations since data was not available for Trinidad and Tobago

${ }^{30}$ Based on 23 observations since data was not available for Solomon Islands.

${ }^{31}$ Based on 23 observations since data was not available for Solomon Islands.

${ }^{32}$ Based on 23 observations since data was not available for Solomon Islands.

${ }^{33}$ Based on 23 observations since data was not available for Solomon Islands.
} 
Table 3

What Explains Mechanism Choices? - Multinomial Analysis.

THE DEPENDENT VARIABLES: For completeness and statistical accuracy we conducted Multinomial analysis that included 4 categories: Uniform, Discriminatory, Both and Other mechanism. We present here only the comparison between the Uniform and the Discriminatory mechanism. Discriminatory Mechanism is the comparison group. THE DEPENDENT VARIABLES: dummy for Indebtedness Classification. (Source: World Bank- 2003.) The World Bank classifies countries by their level of indebtedness for the purpose of developing debt management strategies. It uses a three-point scale: severely indebted (S), moderately indebted (M), and less indebted (L). The Indebtedness classification also serves as proxy for the riskiness of the country. Civil (Roman) Law versus Common Law. This variable was proposed by La Porta et al (1998). We try to see whether the auction mechanism is associated with the legal system in a country. Stock Market Capitalization as Percentage of the GDP. (Source: World Bank - 2003.) Market capitalization is the share price times the number of shares outstanding and is calculated as percentage of the GDP. GDP. (Source: World bank - 2003.) GDP is measured in current US dollars. Ease of Doing Business 2006.(source: IFC - published in 2005)

$\mathrm{Z}$ values are in parenthesis. $* *=$ significant at $5 \%$ level. $*=$ significant at $10 \%$ level.

We estimated 4 different specifications as follow.

\begin{tabular}{|c|c|c|c|c|}
\hline & $\mathbf{1}$ & $\mathbf{2}$ & $\mathbf{3}$ & $\mathbf{4}$ \\
\hline CONSTANT & $\begin{array}{c}-2.572^{* *} \\
(-2.995)\end{array}$ & $\begin{array}{c}-0.503 \\
(-0.765)\end{array}$ & $\begin{array}{c}-0.110 \\
(-0.154)\end{array}$ & $\begin{array}{c}-1.535 \\
(-1.233)\end{array}$ \\
\hline Cap / GDP & $\begin{array}{c}0.030 * * \\
(2.579)\end{array}$ & & & $\begin{array}{c}0.025^{* *} \\
(2.075)\end{array}$ \\
\hline $\begin{array}{c}\text { Dummy (Indebtedness } \\
\text { Classification) }\end{array}$ & & -1.069 & & \\
\hline GDP & & $(-1.085)$ & & \\
\hline Dummy (Civil Law) & & $3.66 \mathrm{e}-13$ & $7.60 \mathrm{e}-13$ & \\
\hline & & $(0.847)$ & $(1.459)$ & \\
\hline Pseudo R2 & 0.096 & 0.106 & 0.088 & 0.126 \\
\hline Prob > chi(n) & $0.023^{* *}$ & $0.069^{*}$ & 0.115 & $0.057^{*}$ \\
\hline
\end{tabular}


Table 4

Pearson and Spearman's Rho Correlation Matrix

Spearman rho non parametric correlation result is the lower line. ${ }^{* *}=$ significant at $5 \%$ level. $*$ = significant at $10 \%$ level

\begin{tabular}{|c|c|c|c|c|}
\hline & Civil & Cap / GDP & GDP & $\begin{array}{c}\text { Ease of } \\
\text { Doing } \\
\text { Business } \\
\text { Ranking }\end{array}$ \\
\hline Civil & 1 & $-0.354^{* *}$ & -0.127 & 0.210 \\
& & $-0.368^{* *}$ & 0.113 & $0.276^{*}$ \\
\hline Cap / & & 1 & $0.299^{*}$ & $-0.551^{* *}$ \\
GDP & & & $0.518^{* *}$ & $-0.633^{* *}$ \\
\hline GDP & & & & $-0.279^{*}$ \\
& & & & $-0.407^{* *}$ \\
\hline
\end{tabular}

Civil stands for civil law

Cap stands for capitalization

GDP stands for Gross Domestic Product 


\section{Appendix A - Survey Submitted to Treasuries and Central Banks}

Professors Dan Galai and Dr. Orly Sade from the Finance Department at the School of Business Administration, Hebrew University of Jerusalem and Professor Menachem Brenner from the Finance department at New York University Stern School of Business are conducting academic research in an attempt to better understand auction design mechanism. The two main mechanisms employed by governments around the globe are: the Uniform Price auction (one price, the clearing price, applies to all) and the Discriminatory Price auction (bidders pay their price, which is at and above the clearing price).

The survey is very short and answering it should take only a few minutes. We thank you in advance for your cooperation.

1. Name of the country

2. Does your country use mainly auctions to sell government debt instruments?

a. Yes

b. No

If the answer to question 2 is yes, please continue to question 3. If the answer is no please continue to question 4.

3. What type of auction mechanisms does your country use currently in order to sell government debt instruments?

a. Uniform price mechanism (one price)

b. Discriminatory price mechanism (pay your bid, multiple price mechanism)

c. Other

4. Did your country use in the past a different mechanism to sell government debt?

a. Yes

b. No

If the answer to question 4 is yes please continue to question 5. If the answer is no please continue to question 6.

5. What was the main reason for the change?

6. Does the treasury (or the central bank) have the right to change the quantity of the debt that is being sold after viewing the demand? 

a. Yes
b. No
c. Not relevant

7. Are you aware of any research paper or report (written in English) that is investigation the auction mechanism of government instrument in your country? If you do we would truly appreciate if you can attach a copy to your reply e-mail or refer us to the source.

We would like to thank you for your help. We will obviously be more than happy to share with you the results of this survey. Please indicate to which e-mail to send the working paper:

Thank you,

Menachem Brenner, Dan Galai and Orly Sade 